\title{
CDISC SDTM Age Unit Terminology
}

National Cancer Institute

\section{Source}

National Cancer Institute. CDISC SDTM Age Unit Terminology. NCI Thesaurus. Code C66781.

Terminology codelist used with Age Unit within the Clinical Data Interchange Standards Consortium Study Data Tabulation Model. 